Article

\title{
Corruption and Technological Innovation in Private Small-Medium Scale Companies: Does Female Top Management Play a Role?
}

\author{
Houxue Xia ${ }^{1,2}$, Qingmei Tan ${ }^{1}$ and Junhong Bai ${ }^{3, *}$ \\ 1 College of Economics and Management, Nanjing University of Aeronautics and Astronautics, \\ Nanjing 211106, China; xiahouxue@126.com (H.X.); tanchangchina@sina.com (Q.T.) \\ 2 Business School, National University of Singapore, Singapore 118699, Singapore \\ 3 Business School, Nanjing Normal University, Nanjing 210023, China \\ * Correspondence: e0264671@u.nus.edu; Tel.: +86-25-5211-9019
}

Received: 22 April 2018; Accepted: 25 June 2018; Published: 29 June 2018

\begin{abstract}
Common acts of corruption such as bribery and informal payments are virtually illegal everywhere and prevalent in every corner of the world. This paper aims to contribute to the literature by considering the influences of corruption and female top management on the likelihood of technological innovation by using a nationwide survey and a sample of private small-medium sized companies (SMCs) in China. Interestingly, we find that female top managers have less enthusiasm for innovation than their male counterparts. Corruption, when measured by informal payments, poses a positive effect on the possibility of innovation after controlling for firm-level characteristics. However, female executives may weaken the positive innovation effects caused by corruption. Furthermore, one of our implied findings is that a firm with a female top manager is less likely to engage in corruption because this may raise the costs of doing business without any benefits for innovation. The results collectively illustrate the role that female top management and corrupt actions have in shaping innovative activities of private SMCs, and suggest that bribe-combating actions in firms are necessary, such as a framework for rationalizing the proportion of female executives involved in management.
\end{abstract}

Keywords: corruption; technological innovation; female top management; China

\section{Introduction}

Over 40 years after implementing the reform and opening policy, the Chinese economy has advanced from a poor country to become a middle-income country. It is noted that higher economic growth often goes together with a high level of innovation and a low level of corruption. However, this may not be the case in China. Despite the various anti-corruption campaigns, studies and practices show that corruption is still widespread in China. A few years ago, a gender dimension was considered to this field through the classic article issued by Dollar et al. [1]. Some studies on gender and/or corruption demonstrate that the phenomenon of innovation is gendered. The near-complete focus on corruption in business-related disciplines is striking, since a company's involvement in corruption is basically driven by top managers' decisions [2]. Theoretically, although the effect of corruption on innovation cannot be explained by one single extant theory, the research that corruption affects innovation forms two major fields. One view argues that corruption is like "grease" for a firm's growth and another is considered to be "sand" for a firm's growth. We claim that whether corruption is seen as "sand" or "grease" for a firm's growth is largely determined by the manager's decision and contextual factors. Although previous research on corruption at a country level shows that corruption is regarded as the "grease" for enterprise's innovation in a transition economy, few studies have demonstrated the 
effects of corruption on innovation at the firm level. Particularly, little research provides a theoretical overview regarding how female top management affects the relationship between corruption and technological innovation in private small-medium-scale firms. Hence, this article examines the effects of corruption on technological innovation and whether female top management plays a role in this effect.

In another approach, a firm's behavior is explained by upper-echelon theory [3]. This is one of the most popular perspectives in transitional economies. The upper-echelon theory shows that women possibly behave differently from men in many economic circumstances [4] and corruption may not affect a firm's performance because paying bribes is simply an entry cost of firms to facilitate their survival in their environment. It places pressure on other firms to follow their behaviors when neighboring firms pay informal costs. As a result, corruption and gender pose little impact on a firm's performance. However, several studies have voiced that this observed relationship between gender and corruption was not causal and was likely driven by the omission of other factors which may be correlated with women's participation in top management. As Swamy et al. [5] pointed out, lower corruption is also correlated with women's presence in the labor force.

Based on the upper-echelon theory, this work starts by pointing out that the terms "innovation" and "corruption" used in previous studies are relatively broad measures and cannot make clear how female top management affects the relationship between corruption and innovation. In particular, as a very widespread form of corruption in most tradition economies-especially in China-we will use "informal payments" to redefine corruption and take the female top management into consideration when discussing the relationship between corruption and innovation. More directly, we develop and test hypotheses that link a firm's involvement in corruption to top managers' characteristics and their rationalization of corruption or innovation. In addition, our focus on top management allows us to speak to the importance of organization decision makers and their personal characteristics in explaining variance in a firm's illegal transactions. It is also noted that many studies have found that innovation efficiency and activity of privately owned small and medium companies (SMCs) is much higher than that of state-owned enterprises [6]. For SMCs with limited resources, taking informal payments to seek political connections and launching innovative activities are two mainly sustainable development paths [7]. More directly, the high risk of investment in SMCs' innovative activities may lead managers who tend to avoid risks to substitute innovation with corruption [8]. This study draws on a survey of more than 1700 top-level managers in China and examines the role of female top management in eliminating the innovation effect caused by corruption. The design of this article allows us to consider female top management as a moderator variable to address corruption influencing a firm's innovation, the innovative strategy difference between a male top manager and a female top manager. In terms of methodology, several empirical challenges occur when considering the role of female top management in moderating the linkage between corruption and innovation, for example, the firm's unobservable characteristics and the endogeneity of core variables. Fortunately, following Buis [9], we overcome these problems by using the command "margins" in Stata and can test empirically the impact of a female top manager on the relationship between corruption and innovation.

Interestingly, contrary to the many findings of earlier studies, we find that firms with female top managers are less likely to engage in bribery because this may raise the costs of doing business without any benefits for innovation. Female top managers have less enthusiasm for innovation than their male counterparts by more directly placing constraints on innovation. In addition, the corruption when measured by informal payments poses a positive effect on the likelihood of innovation after controlling for firm-level characteristics. Owing to its focus on female top management, this article provides new insights into the nature of illegal activities, and the value of using a gender perspective when exploring the roots of corrupt behavior. 


\section{Theory and Hypotheses}

\subsection{Theoretical Framework}

According to institutional theory, companies must actively respond to informal requirements and strive to obtain the key resources to survive and achieve positive performance [10]. Generally, the institutional environment determines the selection of a firm which includes market or non-market strategies. Under such circumstances, SMCs tend to establish links with the government to obtain critical resources such as business licenses and permits. Particularly, the close relationship between firms and governments is strengthened in transition economies [11] which are characterized by weak regulatory infrastructure and more informality. In this context, government officials have greater discretion over resource allocation that thus give them more opportunities to squeeze illegal payments from SMCs. As a result, the SMCs' transaction cost for those key resources may increase. Furthermore, the strong dependent linkage with government officials drives SMCs to adopt corrupt actions to reduce uncertainty.

Since Hambrick and Mason [3] put forward upper-echelon theory, however, researchers have begun to pay attention to the contribution of female executives and claim that companies' outcomes are partially forecasted by managerial characteristics [12]. Along with the economic development and the reform deepening in transition economies, the possibility of a female engaging in management increases, which may affect the opportunistic behaviors and corruption of SMCs. According to upper-echelon theory, organizational outcomes largely depend on the characteristics and decisions of firm leaders, and the relative heterogeneity or diversity of characteristics among team members may be associated with firm performance. Consequently, if demographic diversity has inspiration for top manager's behaviors and those behaviors play a key role in effective management, then heterogeneity of the top team is likely to be reflected in firm performance. Specifically, female management may reduce a SMC's dependence on the government because women may have higher levels of ethical actions [1]. More directly, a firm with a female top manager is more likely to use market strategies to promote firm performance and reduce the transaction process with government.

Additionally, feminist theory has claimed that innovation concept is highly gendered and there is a strong male connotation [13]. Previous literature claims that there is a close association between science and engineering and innovation and that these processes are mainly towards men or offered by men. In recent years, female in business sectors have come to play an increasingly significant role in management and innovative activities. The type of innovations supported by public bodies and regarding how innovation is measured in national statistics have shown why innovation is gendered [14]. More and more business sectors are required to maintain a reasonable proportion of females in management to improve firm performance. However, female managers can push themselves through the innovation pipeline, but their role as innovators in not taken for granted because masculine discourses still dominate. Thus, in transition economies, gender discrimination erodes the value of female management and reduces the probability of innovation. We propose the theoretical model in Figure 1 to demonstrate the impact of female top executives on the relationship between corruption and innovation.

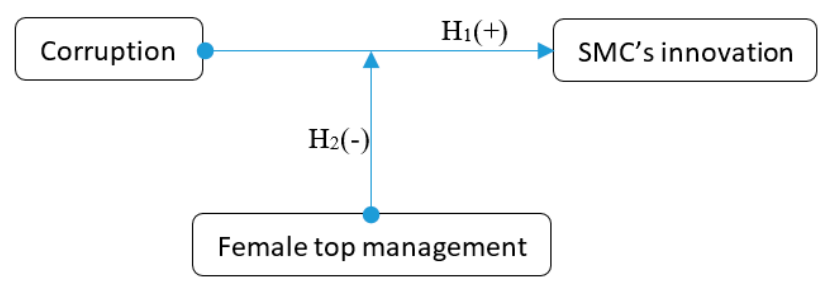

Figure 1. A framework of corruption, innovation, and female top management. 


\subsection{Innovation and Corruption in Privately Owned SMCs}

The effect of corruption on a firm's innovation, whether negative or positive, remains unclear. One strand of the literature suggests that corruption trend to take place in a transition economy with a low quality of governance and can, therefore, reduce the inconvenience of such a transition economy. This view claims that corruption is like "grease" for a firm's innovation [15] and helps companies to overcome bureaucratic processes, complex market access regulations and improve their entry strategies and investment selections. Another strand stresses that corruption is the "sand" for a firm's growth. As pointed out by Van $\mathrm{Vu}$ et al. [16], corruption may corrode the efficient allocation of pivotal resources determining the reputation and culture of companies, and the motivation for companies' innovation. Some claim that corruption imposes many costs on society and these costs may result in lowering or driving profit away from sectors and innovation not being fully valued. In addition, corruption impedes new business sectors' entrance because the incumbents subjectively exploit their corrupt relationship with government officials to delay transactions and the officials tend to extract more bribes from the new companies [17]. It may arise strictly between private parties and often takes place between profit-driven business sectors and public officials or representatives [18]. Privately owned SMCs with limited resources entering less developed countries with weak institutions prone towards corruption are well advised to build regular strategies for dealing with official corruption [19]. Their size and scope mean that being aloof from political connections may lessen the motivation for carrying out innovative activities and how well these business groups are supervised is therefore highly significant to these countries' business sectors. For the most part, in tradition economies, SMCs can pursue growth not only by innovation where the cost of launching innovative activities is lower than that of building the connections with government officials but also corruption where it brings more revenue than innovation costs [20]. From a theoretical point of view, several disciplines-criminology, predominantly social psychology, and managements-have put forward different frameworks and causes that may explain why SMCs engage in corruption [21]. These documents have formed two opposite conclusions regarding how corruption influences SMCs' innovative activities. On the one hand, the pursuit of innovation is characterized by the presence of information asymmetries and non-determinacy that originate from the fact that innovation includes new and untried combinations of ends-means relationships [22]. Yet corruption necessarily increases the level of uncertainty and ambiguity that the innovator must bear and exposes the prospective innovator to agency costs, which is associated with the risk that an agent might later demand additionally informal payments for some services rendered. This is to say, the costs of corruption are commonly sufficient to deter SMCs from attempting to exploit growing emerging and frontier market opportunities and thus the SMCs may seek innovative chances to achieve sustainable development.

On the contrary, an abundance of theories and articles hold the view that corruption plays a vital role in seeking profit for SMCs. As some even pointed out, it is the primary vehicle for driving a development to a less developed nation [23]. Generally, SMCs with poor technologies, training programs and so forth are understandably reluctant to conduct innovative activities where gains may be more than offset by the potential costs of seeking resources. Engaging in corruption or building a political connection with corrupt officials may get access to their development because the officials' value chain must at some stage involve those entrusted with profit. It is undoubted that they abuse their powers and authorities to secure advantages for SMCs which have an interest in associating with corrupt officials by using "speed money" or informal payments. According to this, corrupt transactions among public sectors and private businesses are a way of circumventing cumbersome and pervasive regulations (red tape) that are advantageous to lower transactional and institutional costs of innovative activities and increase of innovative efficiency. More fundamentally, SMCs often must procure several types of governmental goods such as permits, licenses, and certificates that are complements to each other and offered by different governmental departments to conduct business [24]. If bureaucrats are disorganized and act as profit-interrelated monopolists, then each of them will prefer to maximize one's 
informal individual income by exchanging his own governmental good and, in doing so, will motivate SMCs to create innovation because the uncertainty and ambiguity of entering markets are reduced.

Unlike the worst forms of corruption, informal payments do not commonly involve an outright injustice on the part of the payers, although they may pay more and get less. Informal payments, also known by terms such as expediting payments, tea money or commission fees, are a form of petty corruption and can be defined as "the act of giving a thing of small value in order that an official does something, or does it faster and more effectively". As Moldovan and Van de Walle [25] pointed out, many SMCs consider informal payments as a means of getting access to build a connection with bureaucrats to open a business deal, commercial transaction and the issuance of a permit or license. Ironically it is widespread in developing countries that have high corruption and high growth economies such as China, Indonesia, and Thailand. Some recent evidence lends support to the view that the effects of informal payments depend not only on the scale of SMCs but also on the amoral nature of profiteers [26]. Especially in traditional economies and countries that are unsound, profiteers and bureaucrats are inclined to take advantage of institutional loopholes to illicitly squirrel away huge sums [27]. For an incumbent and a newcomer, to adapt to the disorder of the market, the SMC is committed to dealing with anomie. This also makes more SMCs gain success through bribery (informal payments) and thus corruption may become an important artifice for the survival of an SMC [28]. Therefore:

Hypothesis 1. SMCs that engage in corruption in a transition economy may have a positive relation to their technological innovation.

\subsection{Female Top Management}

Creating innovation is an immense and vital instrument of competition for a SMC whether its top manager is male or not. According to Jha and Sarangi [4], women have an influence on corruption and gender may directly or indirectly reflect the personality characteristics and ways of doing things. Along with the deepening of research, theories related to human capital, resource dependence, social psychology and principal-agent as shown in Table 1 have found an increasingly wide utilization in the field that female executives may have a great effect on innovation. The role of female top managers in innovative activities seems not to be uniform through these theories.

Table 1. Theoretical perspectives on role of female top management.

\begin{tabular}{|c|c|c|c|}
\hline Aspects & Types of Theories & Core Contents & The Role of Female Top Management \\
\hline \multirow[t]{2}{*}{$\begin{array}{l}\text { Organizational } \\
\text { perspective }\end{array}$} & Resource dependence & $\begin{array}{l}\text { Each organization must seek } \\
\text { development resources from an } \\
\text { open environment }\end{array}$ & $\begin{array}{l}\text { Providing diverse perspectives and } \\
\text { solutions to managerial decisions and } \\
\text { bringing more internal support and } \\
\text { external resources }\end{array}$ \\
\hline & Principal-agent & $\begin{array}{l}\text { The function of the board of directors is } \\
\text { to monitor and control the managers }\end{array}$ & $\begin{array}{l}\text { Role of female managers on companies' } \\
\text { access to resources is not clear }\end{array}$ \\
\hline \multirow{2}{*}{ Team perspective } & Upper Echelons & $\begin{array}{l}\text { companies' outcomes-strategic choices } \\
\text { and decisions-are partially forecasted } \\
\text { by managerial characteristics }\end{array}$ & $\begin{array}{l}\text { Female executives' characteristics and ways } \\
\text { of doing things have an obvious influence } \\
\text { on strategic choices and team performance }\end{array}$ \\
\hline & Social cognition & $\begin{array}{l}\text { The minority is subordinate to the } \\
\text { majority and the lower level to the } \\
\text { higher level }\end{array}$ & Powerless that cannot play their role \\
\hline \multirow[t]{2}{*}{$\begin{array}{l}\text { Personal } \\
\text { perspective }\end{array}$} & Human capital & $\begin{array}{l}\text { In economic growth, the role of human } \\
\text { capital is greater than that of material } \\
\text { capital. The economic benefit of } \\
\text { investment in human capital is more } \\
\text { than that of material investment }\end{array}$ & $\begin{array}{l}\text { The human capital characteristics of female } \\
\text { executives are different from that of male } \\
\text { top managers and benefit to innovative } \\
\text { performance }\end{array}$ \\
\hline & Feminism & $\begin{array}{l}\text { In accepting higher education and } \\
\text { having the right to vote, women should } \\
\text { get equal opportunities with men }\end{array}$ & $\begin{array}{l}\text { It is a woman's job to nurture and care for } \\
\text { the family and that has a negative influence } \\
\text { on innovation }\end{array}$ \\
\hline
\end{tabular}


Also, some researchers noted that while in United Stated both females and males have similar science and math achievement examinations in school, men exceed women at the top levels of technology and engineering, and girls receive $30 \%$ of the physical science degrees compared to $70 \%$ of boys and only about $17 \%$ of doctorates in engineering science are received by females [29]. Furthermore, several types of research have demonstrated that women prefer to pursue liberal arts degrees than men and that men are more ubiquitous in technical fields of studies. These indicate that the significant gender gap in pursuing science and engineering doctorates may lead to an obvious difference between female and male managers in innovative activities.

In addition, the non-negligible causality between gender, innovation, and corruption has only recently gained a wider interest among scholars within the entrepreneurship and management fields. One of the reasons for the lack of articles taking a top manager's gender perspective to corruption, compared to the growing amount of research on innovation and gender, is the apparent invisibility of people in corrupt activities. When these activities are not visible in the discourse, gender easily becomes invisible. Some articles stress that individualist and collectivist cultures provide not only monetary incentives for innovation but also social status rewards, leading to higher rates of innovation. [30,31]. Likewise, the experimental evidence states that immoral behaviors by top managers can induce cheating action in subordinates [32]. Another study, for example, made known that male top managers engaging in corruption are inclined to rationalize their behaviors as a necessity for being competitive [2]. Moreover, some noted that informal payments, as a means of corruption, pose a high sense of irresponsibility, which occasionally occurs at a banquet, and officials involved in it prefer to ask for money or gifts from male business owners [33].

As indicated by much of the literature, corrupt behavior can become accepted practice and corruption can become institutionalized in SMCs and rationalized by organizational members, especially top executives [34]. In line with these studies, female top managers in SMCs are associated with a lower incidence of bribery and a more positive outlook regarding the influence of corruption on doing business. However, female top managers may pose a detrimental effect on SMCs' innovation, because not paying informal money or gifts to a corrupt politician might be seen as threatening to the dominant regime and provoke retaliation [35]. Consequently, these companies supervised by female top managers cannot obtain the extra benefits and resources from political bureaucrats. In other words, as Figure 1 reveals, female top management is a rationally moderate variable that acts on the relationship between corruption and innovation. Therefore:

Hypothesis 2. Female top management significantly moderates the relationship between corruption and innovation.

\section{Research Methodology}

\subsection{Data and Sample}

The data of variables comes from the World Bank's "China-Enterprise Survey 2012" (CES) http://www.enterprisesurveys.org/. The World Bank interviewed a representative sample of the private sector composed of 2700 business establishments from November 2011 through March 2013 across 25 of the largest cities in China. It covers several topics of the business environment as well as performance measures for each firm (See full methodology at the CES website). Like many secretive things that are too embarrassing to mention, corruption is relatively difficult to quantify. However, the CES, which started about 15 years ago, is highly typical firm-level survey that is well-designed and implemented according to the propositions in previous literature. Drawing on Breen et al. [35], we consider a firm's informal payment as evidence of participation in corruption. By dealing with incomplete or missing data, our dataset contains observations on over 25 central cities, 20 industries, and 1700 sample firms in China, though our sample size depends primarily on our choice of dependent and independent variables. According to the World Bank, we regard a firm with more than 5 employees and less than 99 people as a small and medium company. 


\subsection{Measures}

\subsubsection{Dependent Variables}

Technological innovation. The independent variable comes from questions which record innovation: "in what type of innovative activities has this establishment engaged?". The options are: (i) "Introduce new technology and equipment(s) for product or process improvements" (ii) "Introduce new quality control procedure in production or operations" (iii) "Introduce new managerial/administrative processes" (iv) "Provide technology training for staff" (v) "Introduce new product or new service" (vi) "Add new features to existing products or services" (vii) "Take measures to reduce production cost" and (viii) "Take actions to improve production flexibility". According to Cuijpers et al. and Zhai et al. [36,37], we use the options (v) and (vii) to indicate the emblematical innovation of enterprise because the conversion of creative ideas into new products and processes has long been considered a central challenge in innovation [38]. The two kinds of activities basically represent the two categories of technological innovation, namely, product innovation and process innovation. Accordingly, "1" means an enterprise carried out the two activities and " 0 " shows that an enterprise did not carry out any of the two activities. Additionally, we consider option (i) as an alternative measure of a firm's innovation to test the robustness of our regression results.

\subsubsection{Independent Variables}

Corruption. We use the annual informal payment derived from the following question to measure corruption. Reinikka and Svensson [39] remarked that it is better to ask this type of question than one that seeks information about the interviewees' own company.

It is said that establishments are sometimes required to make informal payments or gifts to public officials to "get things done" with regard to licenses, regulations, services and so forth. On average, what percentage of total annual sales, or estimated total annual value, do establishments like this one pay in informal payments or gifts to public officials for this purpose?

The phrase "get things done" is more conciliatory and likely to reduce respondents' vigilance. Moreover, recent documents claimed that non-reticent interviewees are less likely to lie about corruption than reticent respondents but that women are more likely to be non-reticent than men. As Clarke [40] pointed out, managers are inclined to overestimate bribes when they report informal payments in percentage terms. On the other hand, the Logit model requires us to use " 0 " or " 1 " to indicate the variables in the regression equation. Therefore, we decide not to use the information of informal payments as a percentage of total annual sales because of the possibility of measurement error. Consequently, we convert this question into "does giving informal payments or gifts to public officials to get things done" and use " 1 " to represent "YES", "0" to represent "NO".

Female top management. Another explanatory variable of interest comes from the question "is the top manager female (Yes $=1$ and No $=0$ )". Notice that the top manager is defined as the "highest management individual" by the World Bank's manual.

\subsubsection{Control Variables}

We control for several indispensable firm characteristics potentially affecting innovation. The following are consolidated from different strands of literature such as firm size, R\&D investment, problems with access to finance, market competition, firm age, and labor regulations. We use the number of employees to measure the size of an enterprise. The R\&D investment is measured by a question on whether the establishment spends on research and development activities. Firm age is defined as "Log (2012-year establishment formally registered)". According to the World Bank, the remaining variables which are coded on a 4-point Likert-type scale are measured by questions and responses as shown in Table 2. As most indicators are given as discrete variables, we estimate Logit 
models. In addition, we include dummies for city and industry type to control the influence of them on innovation.

Table 2. Measurements of market competition, access to finance, and labor regulation.

\begin{tabular}{lccccc}
\hline Options & No Obstacle & Minor Obstacle & Moderate Obstacle & Major Obstacle & Very Severe Obstacle \\
Variables & 0 & 1 & 2 & 3 & 4 \\
Market competition & 0 & 1 & 2 & 3 & 4 \\
Access to finance & 0 & 1 & 2 & 3 & 4 \\
Labor regulations & & & & & \\
\hline
\end{tabular}

Questions: Using the response options on the card, to what degree is market competition/access to finance/labor regulation an obstacle to the current operations of this establishment?

Tables 3 and 4 report summary statistics and correlation matrix. All variables come from the World Bank's "China-Enterprise Survey 2012" and the correlation coefficient between any two variables is less than 0.40 . The 20 industries in our dataset come from manufacturing and service sectors and the former accounts for more than $90 \%$. On face value, firms where women are top managers pay less in bribes than those where men are in positions of influence. Please note that c_ female top manager and c_corruption are respectively centralizations of variables "female top manager" and "corruption" and designed to prevent the emergence of multiple collinearities. Accordingly, c_female top manager

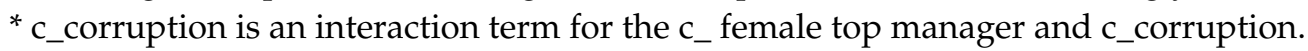

Table 3. Summary statistics.

\begin{tabular}{lccccc}
\hline \multicolumn{1}{c}{ Variables } & Obs. & Mean & S.D. & Min. & Max. \\
\hline 1. Firm age in log & 1757 & 2.83 & 0.36 & 1.61 & 4.87 \\
2. Market competition & 1757 & 0.83 & 0.86 & 0 & 4 \\
3. R\&D investment & 1697 & 0.42 & 0.49 & 0 & 1 \\
4. Innovation & 1517 & 0.37 & 0.48 & 0 & 1 \\
5. Innovation (alternative measure) & 1697 & 0.63 & 0.48 & 0 & 1 \\
6. Corruption & 1196 & 0.20 & 0.40 & 0 & 1 \\
7. Firm size in log & 1757 & 4.44 & 1.34 & 1.61 & 10.82 \\
8. Labor regulations & 1757 & 0.52 & 0.71 & 0 & 4 \\
9. Access to finance & 1757 & 0.83 & 0.87 & 0 & 4 \\
10. Female top manager & 1757 & 0.59 & 0.49 & 0 & 1 \\
11. c_gender & 1757 & 0.00 & 0.49 & -0.58 & 0.41 \\
12. c_corruption & 1196 & 0.00 & 0.40 & -0.20 & 0.80 \\
13. c_female top manager * c_corruption & 1196 & 0.03 & 0.20 & -0.47 & 0.33 \\
\hline
\end{tabular}


Table 4. Correlation matrix.

\begin{tabular}{|c|c|c|c|c|c|c|c|c|c|c|c|c|}
\hline Variables & 1 & 2 & 3 & 4 & 5 & 6 & 7 & 8 & 9 & 10 & 11 & 12 \\
\hline 1. Firm age in log & 1.00 & & & & & & & & & & & \\
\hline 2. Market competition & -0.00 & 1.00 & & & & & & & & & & \\
\hline 3. R\&D investment & $0.06^{* *}$ & $0.06^{* *}$ & 1.00 & & & & & & & & & \\
\hline 4. Innovation & -0.02 & $-0.01 *$ & $0.07^{* * *}$ & 1.00 & & & & & & & & \\
\hline 5. Innovation $b$ & $0.06^{* *}$ & $0.10^{* * *}$ & $0.38^{* * *}$ & $0.28^{* * *}$ & 1.00 & & & & & & & \\
\hline 6. Corruption & 0.01 & -0.02 & $0.09 * * *$ & $0.13^{* * *}$ & $0.13^{* * *}$ & 1.00 & & & & & & \\
\hline 7. Firm size in log & $0.26^{* * *}$ & $-0.09 * * *$ & $0.23 * * *$ & 0.04 & $0.17^{* * *}$ & 0.01 & 1.00 & & & & & \\
\hline 8. Labor regulations & 0.04 & $0.25^{* * *}$ & $0.09 * * *$ & 0.02 & $0.11 * *$ & -0.01 & $0.05 *$ & 1.00 & & & & \\
\hline 9. Access to finance & -0.03 & $0.22^{* * *}$ & $0.14^{* * *}$ & 0.02 & $0.14^{* * *}$ & 0.03 & 0.01 & $0.37^{* * *}$ & 1.00 & & & \\
\hline 10. Female top manager & 0.07 & $0.06 * *$ & $-0.09^{* * *}$ & $-0.17^{* * *}$ & $-0.08 * * *$ & $-0.14^{* * *}$ & 0.03 & $0.31^{* * *}$ & -0.03 & 1.00 & & \\
\hline 11. c_gender & 0.07 & $0.06 * *$ & $-0.09 * * *$ & $-0.17^{* * *}$ & $-0.08^{* * *}$ & $-0.14^{* * *}$ & 0.03 & $0.031^{* * *}$ & -0.03 & 1.00 & 1.00 & \\
\hline 12. c_corruption & 0.01 & -0.02 & $0.09 * * *$ & $0.13 * * *$ & $0.13^{* * *}$ & 1.00 & 0.01 & -0.01 & 0.03 & $-0.14^{* * *}$ & $-0.14^{* * *}$ & 1.00 \\
\hline 13. $c_{-}$female top manager ${ }^{*}{ }_{\text {c_corruption }}$ & 0.02 & $0.11^{* * *}$ & 0.04 & $-0.17^{* * *}$ & $-0.05^{*}$ & $-0.25^{* * *}$ & 0.03 & $0.07 *$ & 0.03 & 0.04 & 0.04 & $-0.25^{* * *}$ \\
\hline
\end{tabular}




\section{Results}

\subsection{The Influence of Corruption on SMCs' Innovation}

Tables 5-7 present the main findings from the econometric analysis. As a benchmark, linear probability regression results are also reported by using the Ordinary Least Square (OLS) approach. By the force of contrast, we found that the difference between robust standard error and ordinary standard error is very small and thus it is not necessary to doubt whether the model is set correctly. Columns 2-3 of Table 5 shows a positive significant linkage between SMC's innovation and corruption at the $5 \%$ level of significance. The estimated coefficient clearly states that SMCs with corrupt behavior have a higher innovative motivation than those without. It is in line with the findings by Wang and You [41] on Chinese firms. The odds ratio results also tell us that in the case of the given variables the passion for innovation in companies involved in corruption is $64 \%$ higher than that of those without. Accordingly, the average marginal effects suggest that at the $5 \%$ level of significance the marginal contribution of corruption to the likelihood of innovation is 0.09 and the motivation for innovation will increase by $0.29 \%$ if the corruption changes a unit. From these results above, we conclude that there is indeed a connection between corruption and innovation in SMCs, but that it may vary depending on the specific aspect that we focus on. For example, the firm's owner has the power to constrain corrupt behaviors, while the top manager may not have as much of an effect unless he/she is an owner, as he/she may be constrained by opposing groups within the corporate structure [35]. In brief, these results offer supports for Hypothesis 1 and may need to be further verified from a gender perspective.

Table 5. Binary logit regression models of corruption and SMC's innovation.

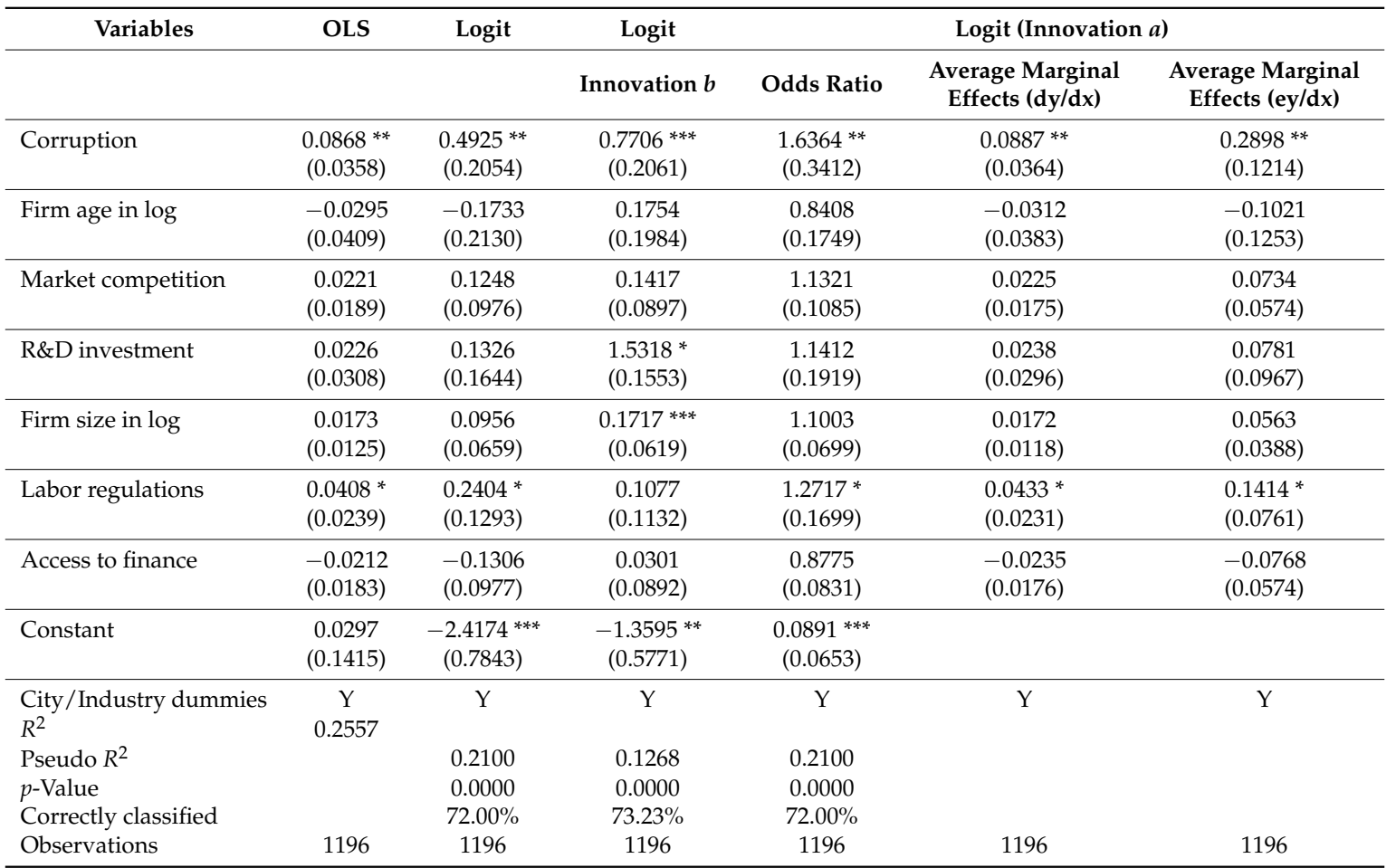

(1) day/dx and ey/dx for factor levels are the discrete change from the base level. (2) Delta-method standard errors of average marginal effects and robust standard errors are reported under each coefficient in parentheses. (3) ***, **and * indicate significance at $1 \%, 5 \%$ and $10 \%$ levels respectively. 
Table 6. Regression results for female top manager and innovation.

\begin{tabular}{|c|c|c|c|c|c|c|}
\hline \multirow[t]{2}{*}{ Variables } & \multirow[t]{2}{*}{ OLS } & \multirow[t]{2}{*}{ Logit } & \multirow{2}{*}{$\frac{\text { Logit }}{\text { Innovation } b}$} & \multicolumn{3}{|c|}{ Logit (Innovation $a$ ) } \\
\hline & & & & Odds Ratio & $\begin{array}{l}\text { Average Marginal } \\
\text { Effects (dy/dx) }\end{array}$ & $\begin{array}{l}\text { Average Marginal } \\
\text { Effects (ey/dx) }\end{array}$ \\
\hline Female top manager & $\begin{array}{c}-0.0730 * * * \\
(0.0279)\end{array}$ & $\begin{array}{c}-0.4023 * * \\
(0.1459)\end{array}$ & $\begin{array}{l}-0.2946^{* *} \\
(0.1149)\end{array}$ & $\begin{array}{c}0.6688^{* * *} \\
(0.0976)\end{array}$ & $\begin{array}{c}-0.0742 * * * \\
(0.0265)\end{array}$ & $\begin{array}{c}-0.2546^{* * *} \\
(0.0927)\end{array}$ \\
\hline Firm age in log & $\begin{array}{l}-0.0427 \\
(0.0340)\end{array}$ & $\begin{array}{l}-0.2402 \\
(0.1795)\end{array}$ & $\begin{array}{c}0.1207 \\
(0.1568)\end{array}$ & $\begin{array}{c}0.7864 \\
(0.1412)\end{array}$ & $\begin{array}{l}-0.0443 \\
(0.0330)\end{array}$ & $\begin{array}{l}-0.1521 \\
(0.1137)\end{array}$ \\
\hline Market competition & $\begin{array}{c}0.0203 \\
(0.0165)\end{array}$ & $\begin{array}{c}0.1165 \\
(0.0835)\end{array}$ & $\begin{array}{l}0.2209 * * * \\
(0.0720)\end{array}$ & $\begin{array}{c}1.1235 \\
(0.0937)\end{array}$ & $\begin{array}{c}0.0215 \\
(0.0153)\end{array}$ & $\begin{array}{c}0.0737 \\
(0.0528)\end{array}$ \\
\hline R\&D investment & $\begin{array}{c}0.0314 \\
(0.0264) \\
\end{array}$ & $\begin{array}{c}0.1776 \\
(0.1362)\end{array}$ & $\begin{array}{c}1.6626^{* * *} \\
(0.1265)\end{array}$ & $\begin{array}{c}1.1943 \\
(0.1627)\end{array}$ & $\begin{array}{c}0.0328 \\
(0.0251)\end{array}$ & $\begin{array}{c}0.1125 \\
(0.0862)\end{array}$ \\
\hline Firm size in log & $\begin{array}{l}0.0250 * * \\
(0.0097)\end{array}$ & $\begin{array}{c}0.1373 * * * \\
(0.0518)\end{array}$ & $\begin{array}{l}0.1783 * * * \\
(0.0451)\end{array}$ & $\begin{array}{c}1.1472 * * * \\
(0.0594)\end{array}$ & $\begin{array}{c}0.0253 * * * \\
(0.0095)\end{array}$ & $\begin{array}{l}0.0869 * * * \\
(0.0328)\end{array}$ \\
\hline Labor regulations & $\begin{array}{c}0.0547^{* * *} \\
(0.0205)\end{array}$ & $\begin{array}{c}0.3089 * * * \\
(0.1043)\end{array}$ & $\begin{array}{c}0.1453 \\
(0.0957)\end{array}$ & $\begin{array}{c}1.3620 * * * \\
(0.1420)\end{array}$ & $\begin{array}{c}0.0570 * * * \\
(0.0190)\end{array}$ & $\begin{array}{l}0.1956 * * * \\
(0.0662)\end{array}$ \\
\hline Access to finance & $\begin{array}{c}0.0010 \\
(0.0162)\end{array}$ & $\begin{array}{c}0.0035 \\
(0.0839)\end{array}$ & $\begin{array}{c}0.1558 * * \\
(0.0726)\end{array}$ & $\begin{array}{c}1.0035 \\
(0.0842)\end{array}$ & $\begin{array}{c}0.0006 \\
(0.0155)\end{array}$ & $\begin{array}{c}0.0022 \\
(0.0531)\end{array}$ \\
\hline Constant & $\begin{array}{c}0.1010 \\
(0.1167) \\
\end{array}$ & $\begin{array}{c}-2.0783 * * * \\
(0.6692)\end{array}$ & $\begin{array}{c}-1.3898^{* * *} \\
(0.4501)\end{array}$ & $\begin{array}{c}0.1251 * * * \\
(0.0838)\end{array}$ & & \\
\hline $\begin{array}{l}\text { City/Industry dummies } \\
R^{2}\end{array}$ & $\begin{array}{c}\mathrm{Y} \\
0.2047\end{array}$ & $\mathrm{Y}$ & $\mathrm{Y}$ & $\mathrm{Y}$ & $\mathrm{Y}$ & $\mathrm{Y}$ \\
\hline Pseudo $R^{2}$ & & 0.1692 & 0.1413 & 0.1692 & & \\
\hline$p$-Value & & 0.0000 & 0.0000 & 0.0000 & & \\
\hline Correctly classified & & $72.24 \%$ & $67.83 \%$ & $72.24 \%$ & & \\
\hline Observations & 1757 & 1757 & 1757 & 1757 & 1757 & 1757 \\
\hline
\end{tabular}

${ }^{* * *} p \leq 0.01,{ }^{* *} p \leq 0.05,{ }^{*} p \leq 0.10$. Robust standard errors are reported under each coefficient in parentheses.

Table 7. Female top management and corruption (dependent variable: corruption).

\begin{tabular}{|c|c|c|c|c|c|}
\hline \multirow[t]{2}{*}{ Variables } & \multirow[t]{2}{*}{ OLS } & \multirow[t]{2}{*}{ Logit } & \multicolumn{3}{|c|}{ Logit } \\
\hline & & & Odds Ratio & $\begin{array}{l}\text { Average Marginal } \\
\text { Effects (dy/dx) }\end{array}$ & $\begin{array}{c}\text { Average Marginal } \\
\text { Effects (ey/dx) }\end{array}$ \\
\hline Female top manager & $\begin{array}{l}-1.3715^{* * *} \\
(0.1128)\end{array}$ & $\begin{array}{l}-0.9641 * * \\
(0.5413)\end{array}$ & $\begin{array}{l}0.7962 * * \\
(0.0120)\end{array}$ & $\begin{array}{l}-0.0154^{* *} \\
(0.0652)\end{array}$ & $\begin{array}{l}-0.1546^{* *} \\
(0.0771)\end{array}$ \\
\hline Foreign ownership (\%) & $\begin{array}{l}-3.2781 * \\
(0.0201)\end{array}$ & $\begin{array}{l}-2.9810^{* *} \\
(0.0812)\end{array}$ & $\begin{array}{l}0.2512 * * \\
(0.0379)\end{array}$ & $\begin{array}{l}-0.0550^{* *} \\
(0.1052)\end{array}$ & $\begin{array}{l}-0.7090^{* *} \\
(0.6180)\end{array}$ \\
\hline Exporter Dummy & $\begin{array}{l}3.1039 * \\
(0.4103)\end{array}$ & $\begin{array}{l}3.3102 * * \\
(0.6451)\end{array}$ & $\begin{array}{l}2.194 * * \\
(0.0579)\end{array}$ & $\begin{array}{l}0.4519 * * \\
(0.1110)\end{array}$ & $\begin{array}{l}0.5847^{* *} \\
(0.2262)\end{array}$ \\
\hline Sales in $\log$ & $\begin{array}{l}0.5201 * * \\
(0.0984)\end{array}$ & $\begin{array}{c}0.4973^{* * *} \\
(0.0811)\end{array}$ & $\begin{array}{l}1.1412 * * * \\
(0.9014)\end{array}$ & $\begin{array}{c}0.2092 * * * \\
(0.0792)\end{array}$ & $\begin{array}{c}0.1943^{* * *} \\
(0.1428)\end{array}$ \\
\hline Constant & $\begin{array}{l}-2.1087^{* *} \\
(0.6711)\end{array}$ & $\begin{array}{l}-2.0783 * * * \\
(0.7021)\end{array}$ & $\begin{array}{l}0.1251^{* * *} \\
(0.8136)\end{array}$ & & \\
\hline $\begin{array}{l}\text { City/Industry dummies } \\
R^{2}\end{array}$ & $\begin{array}{c}\mathrm{Y} \\
0.1943\end{array}$ & $\mathrm{Y}$ & $\mathrm{Y}$ & $\mathrm{Y}$ & $\mathrm{Y}$ \\
\hline $\begin{array}{l}\text { Pseudo } R^{2} \\
p \text {-Value } \\
\text { Correctly classified }\end{array}$ & & $\begin{array}{l}0.1023 \\
0.0000 \\
69.31 \%\end{array}$ & $\begin{array}{l}0.1631 \\
0.0000 \\
69.31 \%\end{array}$ & & \\
\hline Observations & 1196 & 1196 & 1196 & 1196 & 1196 \\
\hline
\end{tabular}

${ }^{* * *} p \leq 0.01,{ }^{* *} p \leq 0.05,{ }^{*} p \leq 0.10$. Robust standard errors are reported under each coefficient in parentheses.

\subsection{Corruption and Innovation: Does Gender Play a Role?}

Tables 6 and 7 respectively demonstrate the impact of female top management on corruption and innovation. In Table 6, the linkage between female top management and innovation appears to be robust at the $1 \%$ level of significance and we find that the female top management but not 
ownership poses a negative impact on the likelihood of a firm's innovation from column 2 to column 3. Specifically, the odds ratio markedly shows that female top managers are $33 \%$ lower than male top managers in motivating firms to carry our innovative activities. The average marginal effects suggest that at the $1 \%$ level of significance the marginal diminishing of gender to innovation is 0.0742 and the likelihood of innovation will decrease $0.25 \%$ if the proportion of female top managers increases a unit, keeping other factors constant.

For the effect of women as top managers on corruption, we draw lessons from Jha and Sarangi [4] and Breen et al. [35] and select some variables such as foreign ownership, exporter situation and sales as the control variables. In Table 7, the correlation between female top management and corruption appears to be robust at the $1 \%$ or $5 \%$ level of significance and we find that female top management also exerts a negative influence on the firm's corrupt acts from column 2 to column 3 . Compared to Table 6, the odds ratio demonstrates that female top managers are $20 \%$ lower than male top managers in corrupt acts. The average marginal effects suggest that at the $5 \%$ level of significance the marginal diminishing of gender to corruption is 0.0154 and the probability of an enterprise to engage in corruption will be reduced by $0.15 \%$ if the proportion of female top managers increases a unit.

Looking more closely, the term of interaction between female top managers and corruption was entered into the model to investigate the role of female top management on moderating the relationship between a firm's innovative potential and corruption. As demonstrated in Figure 2, the positive effect of corruption on the likelihood of a firm's innovation is weakened when a firm's top management is a female. Regarding the role of female top manager, the estimated results suggest that the interaction between female top managers and corruption significantly contributed to the explanation of the possibility of innovation. This suggests that if the firm's top manager is female, then the incentive for corruption to innovate in this business will diminish. In other words, top manager gender influences the effect of corruption on innovation. More directly, female top manager poses a negative impact on the facilitation of corruption to innovation. On the other hand, a female top manager has a modest, negative effect on the likelihood of engaging in innovative activities. Compared to Table 6, the association between gender and innovation is weaker but also present at $10 \%$ level of significance.

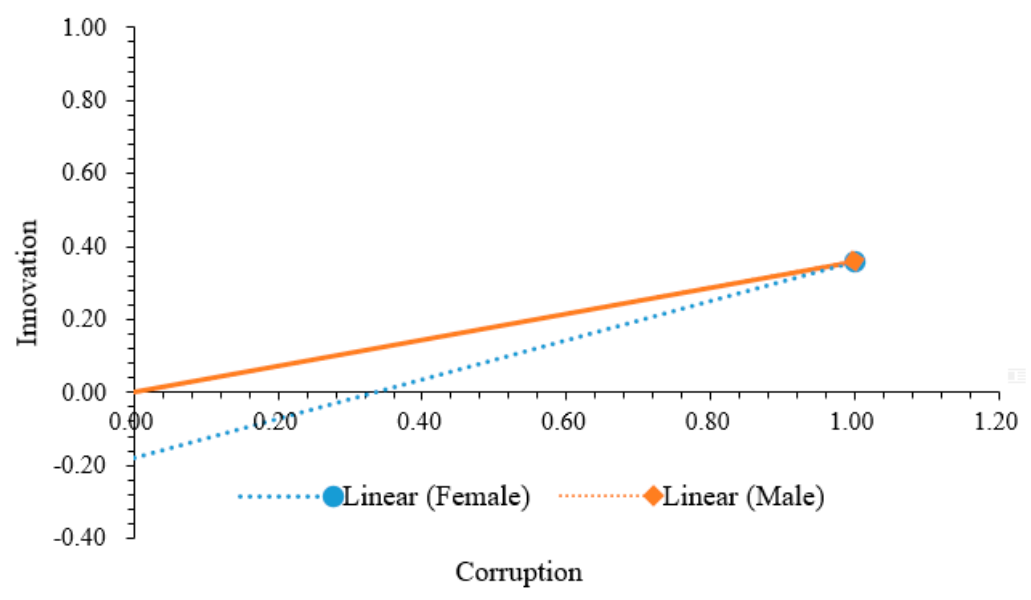

Figure 2. Moderating role of female top management.

Notably, the correlation shown in Table 5 between corruption and likelihood of the firm engaging in innovative activities seemed to indicate a very significant relationship. However, when included in the full regression models presented in Table 8, the positive effect of corruption on innovation has declined. This means that female executives cannot only weaken the role of corruption but also reduce firms' enthusiasm for testing out new products and processes. However, from another perspective, corruption may deepen the adverse effects of female executives on firms' innovation. More specifically, column 6 of Table 8 reports that a female top manager engaging in corrupt transactions will lead 
to a $0.11 \%$ reduction in the likelihood of innovation. The results also show that the likelihood of innovation does not seem to be influenced by most of the control variables included in this model. It is worth noting that labor regulations always pose an effect on the possibility of innovation, regardless of which model is used. It may be that firms with higher labor regulations can force managers into value-maximizing decisions and thus to gain higher productivity and innovative performance. The above findings imply that female top managers can inhibit the positive impact of corruption on the likelihood of innovation. Furthermore, it also indirectly suggests that businesses with female executives are less likely to engage in corruption activities because this may increase the operating costs without any benefits for innovation.

Table 8. Regression results of female top management, corruption, and their interaction term.

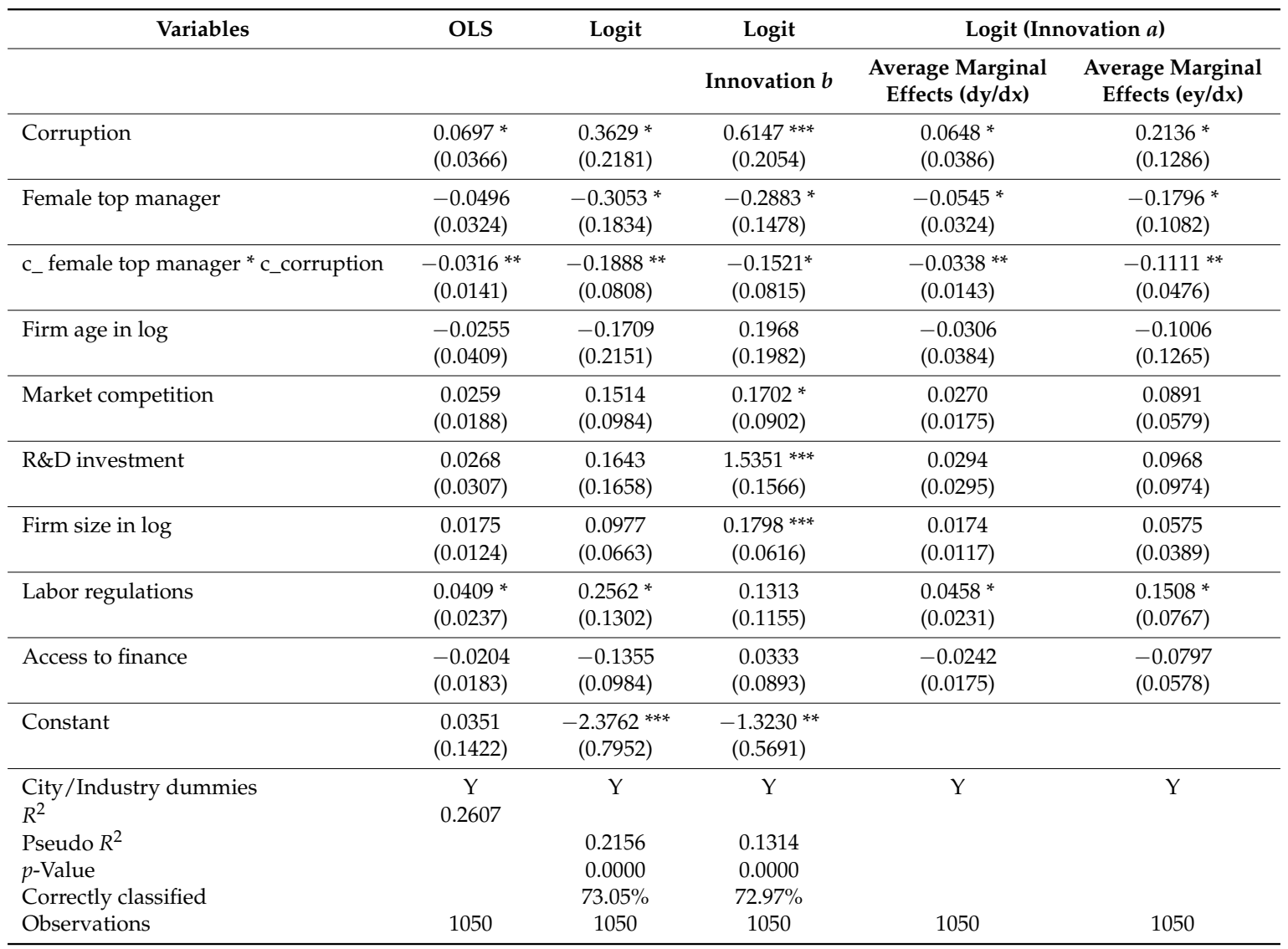

${ }^{* * *} p \leq 0.01,{ }^{* *} p \leq 0.05,{ }^{*} p \leq 0.10$. Robust standard errors are reported under each coefficient in parentheses.

\section{Robustness and Endogeneity}

\subsection{Robustness of the Interaction Term}

In the base case analysis, we consider corruption ${ }^{*}$ female top manager as an interaction term for corruption and female top manager to represent whether the female top manager affects the role of corruption. Some authors pointed out that there is a common mistake in interpreting the first derivative of the multiplicative term between two dependent variables as the interaction effect $[42,43]$. This problem can be explained as the effect of female top manager being the first derivative of the expected value of the dependent variable (E[innovation]) with respect to the female top manager. Buis [9] remarked that the interaction influence should be the cross-partial derivative of $E$ [innovation] with respect to the two explanatory variables. That is typically different from the first derivative of $E$ [innovation] with respect to the multiplicative term corruption $\times$ female top manager. However, 
for our above results, especially Table 6, we just want to explore whether the female top manager affects the role of corruption. Furthermore, as a means of robustness, we use the program suggested by Buis [9] to interpret interaction between corruption and a female top manager without referring to any additional program by presenting effects as multiplicative effects. Table 9 , which was calculated by a Logit model with the or option, reports the results of robustness and how much the impact of female top manager changes for a unit change in corruption. Notably, the dependent variable is measured in the odds metric rather than in the probability metric. The odds of innovation for a firm engaging in corruption with a female top manager is 0.67 and the marginal effect of female top manager for corruption is (-3.918), while the odds of innovation for a firm which is not involved in corruption and has a male top manager is 1.28 . These results show that female executives may not only weaken the role of corruption but also reduce the odds for carrying out innovative activities and prove that the above conclusion is robust and reliable.

Table 9. Robust results of the interaction term.

\begin{tabular}{ccccc}
\hline Corruption $\times$ Female Top Manager & Margin & Delta-Method Std. Err. & $\mathbf{z}$ & $p>\mathbf{z}$ \\
\hline 00 & $1.2847^{* * * *}$ & 0.2032 & 9.05 & 0.000 \\
01 & $0.7318^{* * *}$ & 0.0880 & 10.66 & 0.000 \\
10 & $4.5874^{* * *}$ & 0.1703 & 5.27 & 0.000 \\
11 & $0.6694^{* * *}$ & 0.1860 & 4.32 & 0.000 \\
\hline 0. Corruption $\times$ 1. Female Top Manager & Coef. & Std. Err. & $\mathbf{z}$ & $p>\mathbf{z}$ \\
$(1)$ & $-0.5528^{* * *}$ & 0.2045 & -2.70 & 0.007 \\
\hline 1. Corruption $\times$ 1. Female Top Manager & Coef. $_{(1)}^{* * *}$ & Std. Err. & $\mathbf{z}$ & $p>\mathbf{z}$ \\
& $-3.9180^{* *}$ & 0.1733 & -3.34 & 0.001 \\
\hline
\end{tabular}

$n=1196 .{ }^{* * *} p \leq 0.01,{ }^{* *} p \leq 0.05,{ }^{*} p \leq 0.10$. Each model includes the option 'robust'.

\subsection{Endogeneity of Corruption}

Our study, in line with many theoretical articles, believes that gender is an exogenous variable [44]. While our empirical results hold that corruption improves the likelihood of a firm's innovation, there are also rarely articulated but still valid theoretical reasons for believing that, conversely, the possibility of a firm's innovation may lead to firm engaging in corrupt actions. On the one hand, bureaucrats are more inclined to establish political connections with SMCs to gain benefits illegally and will provide some convenience to the business in return. On the other hand, the aura of power may allow officials to self-select into more successfully innovative firms and these firms may be more likely to respond to officials' actions because they have a greater need for permits, licenses and so forth, or because they have excess resources and greater ability to do so. These arguments suggest that corruption may endogenously depend on firm performance and, thus, that the positive association between corruption and the likelihood of a firm's innovation may be driven by reverse causality.

Accordingly, as an endogeneity and robustness check, we employ the appropriate instrument variable to retest the effect of corruption on a firm's innovation. However, from the perspective of previous literature, there are few references to the instrumental variable of corruption [45]. Ordinarily, it is assumed that the non-individual factors such as industry rules or regional administrations are considered as instrument variables for individual businesses. Hence, we draw on ideas from Besley et al. [46] that regard regional systems or management regulations as instrument variables in reason. Fortunately, the World Bank survey collected the data of local government administration that suggests it may pose an influence on corruption but have an indirect impact on innovative activities of firms. One of our instrument variables (Obstacle) is derived from a survey question that asks "Is [tax administration] No Obstacle, a Minor Obstacle, a Moderate Obstacle, a Major Obstacle or a Very Severe Obstacle to the current operations of this establishment?" and another instrument variable comes from the question "Do you agree the court system is fair, impartial and uncorrupted?" The rationale for these instruments is 
that the more unfair the court system is, the more conducive it is to evade legal supervision and to carry out corruption activities. Strict tax administration regulations and heavy tax rates cause enterprises to evade government control. By bribing public officials, firms can get opportunities for development. The stricter the tax administration, the greater the operational obstacles to the enterprises. As a result, the firms prefer to pay informal payments to avoid tax inspection. Moreover, these instruments are found to be highly positively correlated with informal payments (see Table 9) while there is little reason to believe that court system and tax administration have direct effect on innovation. Consistent with this discussion, we create two dummy variables which take a value of one if the firm feels that tax administration is a major or very severe obstacle and strongly disagrees or tend to disagree that the court system is fair, impartial, and uncorrupted. Before IV regression, the program of a test of over-identifying restrictions shows that we cannot deny the null hypothesis that all instrumental variables are exogenous because the $p$-value is equal to 0.5895 .

Overall, the bottom of Table 10 demonstrates that the values of the Cragg-Donald Wald F statistic and Kleibergen-Paap rk Wald F statistic are over Stock-Yogo weak ID test critical values. Therefore, we claim that tax administration and court system are not weak instruments compared to Stock-Yogo weak ID test critical values. Furthermore, we also present the first-stage regression results in Table 10. Consistent with our previous expectations, we know that the instrument variables have considerably explanatory power for corruption. Tax administration and court system both have significant impact on corruption. These results re-verify the positive effect of corruption on the likelihood of a firm's innovation and the robustness of our above conclusions.

Table 10. Endogenous test: tax administration and court system as instrument variables.

\begin{tabular}{|c|c|c|c|c|c|c|}
\hline & \multicolumn{3}{|c|}{$\begin{array}{c}\text { First-Stage Regressions } \\
\text { (Corruption) }\end{array}$} & \multicolumn{3}{|c|}{ Instrumental Variables Regression (Innovation) } \\
\hline & Coef. & Robust Std. Err. & $\mathbf{t}$ & Coef. & Robust Std. Err. & $\mathrm{z}$ \\
\hline Corruption & & & & $0.1470^{* *}$ & 0.1451 & 2.01 \\
\hline Female top manager & -0.0137 & 0.0265 & -0.52 & $-0.0451^{* *}$ & 0.0322 & -2.40 \\
\hline c_corruption ${ }^{*} c_{-}$female top manager & & & & $-0.0215^{*}$ & 0.2595 & -1.78 \\
\hline Firm age in log & 0.0114 & 0.0286 & 0.40 & -0.0284 & 0.0403 & -0.70 \\
\hline Market competition & -0.0161 & 0.0146 & -1.10 & 0.0251 & 0.0185 & 1.36 \\
\hline R\&D investment & -0.0242 & 0.0258 & -0.94 & 0.0259 & 0.0309 & 0.84 \\
\hline Firm size in log & -0.0086 & 0.0090 & -0.96 & 0.0183 & 0.0123 & 1.49 \\
\hline Labor regulations & 0.0127 & 0.0199 & 0.64 & 0.0393 & 0.0253 & 1.55 \\
\hline Access to finance & 0.0187 & 0.0156 & 1.20 & -0.0224 & 0.0186 & -1.20 \\
\hline Court system & $0.1532^{* * *}$ & 0.0195 & 7.87 & & & \\
\hline Tax administration & $0.1274^{* * *}$ & 0.0453 & 2.81 & & & \\
\hline c_court system ${ }^{*}$ C_gender & 0.0603 & 0.0389 & 1.55 & & & \\
\hline c_tax administration ${ }^{*}$ c_gender & -0.0029 & 0.0667 & -0.04 & & & \\
\hline City/Industry dummies & Y & & & Y & & \\
\hline _cons & 0.1358 & 0.1012 & 1.34 & 0.0239 & 0.1462 & 0.16 \\
\hline \multicolumn{4}{|c|}{ Underidentification test $p$-value } & 0.0000 & & \\
\hline \multicolumn{4}{|c|}{ Cragg-Donald Wald F statistic } & 11.44 & & \\
\hline \multicolumn{4}{|c|}{ Kleibergen-Paap rk Wald F statistic } & 7.07 & & \\
\hline \multicolumn{7}{|c|}{ Stock-Yogo weak ID test critical values } \\
\hline \multicolumn{4}{|c|}{$5 \%$ maximal IV relative bias } & 11.04 & & \\
\hline \multicolumn{4}{|c|}{$10 \%$ maximal IV relative bias } & 6.56 & & \\
\hline \multicolumn{4}{|c|}{$20 \%$ maximal IV relative bias } & 5.57 & & \\
\hline \multicolumn{4}{|c|}{$30 \%$ maximal IV relative bias } & 4.73 & & \\
\hline \multicolumn{4}{|c|}{$10 \%$ maximal IV size } & 16.87 & & \\
\hline \multicolumn{4}{|c|}{$15 \%$ maximal IV size } & 9.93 & & \\
\hline \multicolumn{4}{|c|}{$20 \%$ maximal IV size } & 7.54 & & \\
\hline \multicolumn{4}{|c|}{$25 \%$ maximal IV size } & 6.28 & & \\
\hline
\end{tabular}

\section{Conclusions and Discussion}

In investigating the way in which female top management can affect the linkage between corruption and innovation in small-medium-sized companies, this paper finds that female top management affect a firm's innovative acts and corrupt behaviors, and has a significant negative effect on the innovation effect caused by corruption when observable characteristics are controlled for and robust standard error is used. In terms of traditional firm characteristics, the empirical results are 
generally consistent with other international empirical results which suggest SMCs who engage in corruption in weak institutions have a positive relation to their technological innovation. In particular, female executives can weaken the positive impact of corruption on a firm's innovation. One of our implied findings is that firms with female top managers are less likely to engage in bribery because this may raise the costs of doing business without any benefits for innovation. Furthermore, this paper offers evidence that firms paying informal costs to obtain some kinds of benefits from government officials such as permits, contracts or licenses have positive effects on the likelihood of innovation. Particularly, labor regulations do become statistically significant in the full model and have a positive influence on the possibility of innovation. Taken together, regarding the body of knowledge in this field, this article builds the value of examining corruption and female top management through the influences on the likelihood of innovation in SMCs and of looking beyond regulative measures as a means of reducing corrupt activities. There is clearly opportunity for this body of knowledge to investigate both managerial discretion, upper-echelon theory, and feminist studies. Given the availability of data, our future work could consider firms in other ownership categories, and large enterprises in other business sectors such as agriculture or services to offer a broader explanation of the influence of female top management and corruption on the likelihood of innovation.

In terms of policy implications, although most types of corruption have positive effects on firms' innovation, once the officials' desire is increased or the determination to fight corrupt activities is strengthened, companies will invest more resources to gain benefits from bureaucrats, which may be not worth the loss over the long term. Hence, bribe-combating actions in firms with limited resources are necessary, such as a reasonable framework for rationalizing the proportion of female executives involved in management. On the other hand, building legal and appropriate labor regulations may have an incentive effect on firms' innovation.

Finally, although our study has contributed to the understanding of female top managers' and corruption's effect on the innovation of privately manufacturing and service companies, there remain some limitations that provide opportunities for further research. For example, we focus only on non-state small firms in China and fail to consider the innovative performance of foreign enterprises.

Author Contributions: H.X. conceived, designed and wrote this paper. Q.T. helped to check and revise the spelling and grammar of the article. J.B. generated and analyzed the data. All authors read and approved the manuscript.

Funding: This study was funded by The National Social Science Fund of China (Grant Number: 15BGL029), The National Natural Science Fund of China (Grant Number: 71573138), The Major Project of Jiangsu Social Science Fund (Grant Number: 16ZD008) and Special Task Project of the Humanities and Social Science Research of the Ministry of Education (Grant Number: 16JDGC009).

Acknowledgments: The authors especially thank the editors and anonymous referees for their kindly review and helpful comments. The authors would also like to thank the supports from China Scholarship Council.

Conflicts of Interest: All authors declare no conflict of interest.

\section{References}

1. Dollar, D.; Fisman, R.; Gatti, R. Are women really the "fairer" sex? Corruption and women in government. J. Econ. Behav. Organ. 2001, 4, 423-429. [CrossRef]

2. Collins, J.D.; Uhlenbruck, K.; Rodriguez, P. Why firms engage in corruption: A top management perspective. J. Bus. Ethics 2009, 1, 89-108. [CrossRef]

3. Hambrick, D.C.; Mason, P.A. Upper echelons: The organization as a reflection of its top managers. Acad. Manag. Rev. 1984, 2, 193-206. [CrossRef]

4. Jha, C.K.; Sarangi, S. Women and corruption: What positions must they hold to make a difference? J. Econ. Behav. Organ. 2018, 4, 1-15. [CrossRef]

5. Swamy, A.; Knack, S.; Lee, Y.; Azfar, O. Gender and corruption. J. Dev. Econ. 2001, 1, 25-55. [CrossRef]

6. Jefferson, G.H.; Huamao, B.; Xiaojing, G.; Xiaoyun, Y. R\&D performance in Chinese industry. Econ. Innov. New Technol. 2006, 15, 345-366.

7. Qijing, Y. The growth of enterprises: To build political connections or capability? Econ. Res. J. 2011, 10, 54-66. 
8. Cai, H.; Fang, H.; Xu, L.C. Eat, drink, firms, government: An investigation of corruption from the entertainment and travel costs of Chinese firms. J. Law Econ. 2011, 1, 55-78. [CrossRef]

9. Buis, M.L. Stata tip 87: Interpretation of interactions in non-linear models. State J. 2010, 2, 305-308.

10. Scott, W.R. Institutions and Organizations: Ideas, Interests, and Identities; Sage Publications: Los Angeles, CA, USA, 2013.

11. Xie, X.; Qi, G.; Zhu, K.X. Corruption and New Product Innovation: Examining Firms' Ethical Dilemmas in Transition Economies. J. Bus. Ethics 2018, 2, 1-19. [CrossRef]

12. Bonanno, G.; Haworth, B. The intensity of competition and the choice between product and process innovation. Int. J. Ind. Organ. 1998, 4, 495-510. [CrossRef]

13. Blake, M.K.; Hanson, S. Rethinking innovation: Context and gender. Environ. Plan. A 2005, 4, 681-701. [CrossRef]

14. Marlow, S.; McAdam, M. Analyzing the influence of gender upon high-technology venturing within the context of business incubation. Entrep. Theory Pract. 2012, 4, 655-676. [CrossRef]

15. Méon, P.; Sekkat, K. Does corruption grease or sand the wheels of growth? Public Choice 2005, 122, 69-97. [CrossRef]

16. Van Vu, H.; Tran, T.Q.; Van Nguyen, T.; Lim, S. Corruption, types of corruption and firm financial performance: New evidence from a transitional economy. J. Bus. Ethics 2016, 4, 847-858. [CrossRef]

17. Rose-Ackerman, S. Corruption and development. In Annual World Bank Conference on Development Economics; World Bank: Washington, DC, USA, 1998; pp. 35-57.

18. Kim, E.; Ha, Y.; Kim, S. Public Debt, Corruption and Sustainable Economic Growth. Sustainability 2017, $3,433$. [CrossRef]

19. Luiz, J.M.; Stewart, C. Corruption, South African multinational enterprises, and institutions in Africa. J. Bus. Ethics 2014, 3, 383-398. [CrossRef]

20. Habiyaremye, A.; Raymond, W. Transnational Corruption and Innovation in Transition Economies; UNU-MERIT Working Paper; UNU-MERIT: Maastricht, The Netherlands, 2013; pp. 1-37.

21. Aguilera, R.V.; Vadera, A.K. The dark side of authority: Antecedents, mechanisms, and outcomes of organizational corruption. J. Bus. Ethics 2008, 4, 431-449. [CrossRef]

22. Anokhin, S.; Schulze, W.S. Entrepreneurship, innovation, and corruption. J. Bus. Ventur. 2008, 5, 465-476. [CrossRef]

23. Blackburn, K.; Forgues-Puccio, G.F. Why is corruption less harmful in some countries than in others? J. Econ. Behav. Organ. 2009, 3, 797-810. [CrossRef]

24. De Beer, J.; Fu, K.; Wunsch-Vincent, S. The Informal Economy, Innovation and Intellectual Property-Concepts, Metrics, and Policy Considerations. Economic Research Working Paper; WIPO: Geneva, Switzerland, 2013; Volume 10, pp. 1-76.

25. Moldovan, A.; Van de Walle, S. Gifts or bribes? Attitudes on informal payments in Romanian health care. Public Integr. 2013, 4, 385-402. [CrossRef]

26. Iriyama, A.; Kishore, R.; Talukdar, D. Playing dirty or building capability? Corruption and HR training as competitive actions to threats from informal and foreign firm rivals. Strateg. Manag. J. 2016, 10, 2152-2173. [CrossRef]

27. Acemoglu, D.; Verdier, T. The choice between market failures and corruption. Am. Econ. Rev. 2000, 1, 194-211. [CrossRef]

28. Adhikari, A.; Derashid, C.; Zhang, H. Public policy, political connections, and effective tax rates: Longitudinal evidence from Malaysia. J. Account. Public Policy 2006, 5, 574-595. [CrossRef]

29. Viadero, D. Researches mull STEM gender gap. Educ. Week 2009, 35, 1-5.

30. Gorodnichenko, Y.; Roland, G. Individualism, innovation, and long-run growth. Proc. Natl. Acad. Sci. USA 2011, 108, 21316-21319. [CrossRef] [PubMed]

31. Jha, C.K.; Panda, B. Individualism and Corruption: A Cross-Country Analysis. Econ. Pap. 2017, 36, 60-74. [CrossRef]

32. d'Adda, G.; Darai, D.; Pavanini, N.; Weber, R.A. Do leaders affect ethical conduct? J. Eur. Econ. Assoc. 2017, 6, 1177-1213. [CrossRef]

33. Vian, T.; Grybosk, K.; Sinoimeri, Z.; Hall, R. Informal payments in government health facilities in Albania: Results of a qualitative study. Soc. Sci. Med. 2006, 4, 877-887. [CrossRef] [PubMed] 
34. Ashforth, B.E.; Anand, V. The normalization of corruption in organizations. Res. Organ. Behav. 2003, 25, 1-52. [CrossRef]

35. Breen, M.; Gillanders, R.; McNulty, G.; Suzuki, A. Gender and corruption in business. J. Dev. Stud. 2017, 9, 1486-1501. [CrossRef]

36. Cuijpers, M.; Guenter, H.; Hussinger, K. Costs and benefits of inter-departmental innovation collaboration. Res. Policy 2011, 4, 565-575. [CrossRef]

37. Zhai, Y.M.; Sun, W.Q.; Tsai, S.B.; Wang, Z.; Zhao, Y.; Chen, Q. An Empirical Study on Entrepreneurial Orientation, Absorptive Capacity, and SMEs' Innovation Performance: A Sustainable Perspective. Sustainability 2018, 2, 314. [CrossRef]

38. Van de Ven, A.H. Central problems in the management of innovation. Manag. Sci. 1986, 5, $590-607$. [CrossRef]

39. Reinikka, R.; Svensson, J. Using micro-surveys to measure and explain corruption. World Dev. 2006, 2, 359-370. [CrossRef]

40. Clarke, G.R. How petty is petty corruption? Evidence from firm surveys in Africa. World Dev. 2011, 7, 1122-1132. [CrossRef]

41. Wang, Y.; You, J. Corruption and firm growth: Evidence from China. China Econ. Rev. 2012, 2, 415-433. [CrossRef]

42. Ai, C.; Norton, E.C. Interaction terms in logit and probit models. Econ. Lett. 2003, 1, 123-129. [CrossRef]

43. Cornelißen, T.; Sonderhof, K. Partial effects in probit and logit models with a triple dummy-variable interaction term. Stata J. 2009, 4, 571.

44. Esarey, J.; Chirillo, G. "Fairer sex" or purity myth? Corruption, gender, and institutional context. Polit. Gend. 2013, 4, 361-389. [CrossRef]

45. Lee, S.H.; Weng, D.H. Does bribery in the home country promote or dampen firm exports? Strat. Manag. J. 2013, 12, 1472-1487. [CrossRef]

46. Besley, T.; Burgess, R. Can labor regulation hinder economic performance? Evidence from India. Q. J. Econ. 2004, 1, 91-134. [CrossRef] 